DOI 10.18551/rjoas.2020-05.10

\title{
RISK LEVEL OF HARBORMASTER ACTIVITIES AT FISHING PORT OF NIZAM ZACHMAN, INDONESIA
}

\author{
Sitepu Mestiria Harbani \\ Department of Fishing Technology, Faculty of Utilization Fisheries Resources, \\ Jakarta Fisheries University, Indonesia
}

Krisnafi Yaser*

Faculty of Marine Technology, Pangandaran Marine and Fisheries Polytechnic, West Java, Indonesia

\section{Widagdo Aris}

Department of Fishing Technology, Karawang Marine and Fisheries Polytechnic, West Java, Indonesia

\section{Soeboer Deni Achmad}

Faculty of Fisheries and Marine Science, Bogor Agricultural University, Bogor, Indonesia

\author{
*E-mail: senseiyaser@gmail.com
}

\begin{abstract}
The harbormaster activities of the fishing port are considered to be routine activities without taking into account the hazards resulting from work for fisheries supervisors. This study aims to identify and assess the magnitude of the consequences of the hazards of harbormaster fishing activities. The Hazard Identification and Risk Assessment (HIRA) method was used in data analysis in this study. The results showed that the harbormaster officers' activities at the fishing port consisted of 3 main activities. The results of the analysis using the HIRA method show that the three main activities have an impact on eight types of consequences, namely fatalities, injuries, evaquation, property damage, critical infrastructure, environmental damage, business financial impact and psychosocial impact. The greatest value of the consequences of fishing port harbormaster activities lies in the inspection of fishing vessel departure activities. The total value of consequences is 64 , including the consequence criteria 6, namely extreme. The harbormaster activities of fishing harbor in the pre harbormaster activity giving the biggest consequence value are 24 including moderate criteria. Harbormaster fishing port activities as a whole provide the greatest danger consequences of injuries and property damage.
\end{abstract}

\section{KEY WORDS}

HIRA, fishing, vessel inspection, fishing vessel departures.

Harbormaster Fisheries is at the forefront of service at the Fishery Port. Duties and functions of fishery harbormaster have been regulated in Law Number 45 of 2009 on amendments to Law Number 31 of 2004 concerning Fisheries in article 42 . The main task of the harbormaster fishery is related to the operational safety of fishing vessels which are divided into 16 points of duty and authority.

Harbormaster Fisheries are in every fishing port. Harbormaster at least has the function to supervise and carry out operational safety of fishing vessels and sailing approval for fishing vessels. Control devices used by fisherman harbormaster include proof of ship arrival report, port clearance and issuance of fish catch certification.

Activities undertaken by harbormaster fisheries in conducting services include those carried out by harbormaster fisheries field officers. Fisherman harbormaster field officers are officers who descend directly to inspect the ship physically in the field. This inspection activity certainly has various dangerous consequences. Activities that are routinely carried 
out generally will tend to be ignored the consequences of danger, where this will certainly affect the service at the harbormaster fishery service post.

Based on these problems, it is necessary to know the consequences of the hazards of the fisherman harbormaster field activities as a basis for anticipation in controlling the consequences of the hazards that may occur to fisherman harbormaster officers.

The purpose of this study is to identify and assess the magnitude of the consequences of hazards in the activities carried out by fisherman harbormaster field officers.

\section{MATERIALS AND METHODS OF RESEARCH}

Data collection was carried out by direct observation of inspection activities by harbormaster fishery field officers and interviews of fishing harbormaster field officers at the Nizam Zachman Fisheries Port. This study did not make comparisons or links between variables so that it could be categorized as a descriptive study.

The population in this study is the fisherman harbormaster field officer who is working at the fishery harbormaster service post at the Nizam Zachman Fisheries Port who carries out physical inspection of ships and documents in the field.

The variables studied were hazard identification, risk assessment and risk level assessment on physical inspection and document activities in the field conducted by fisherman harbormaster field officers.

Observations and interviews are intended as a reference for the work process of the fisherman harbormaster fieldworkers activities, potential hazards caused, the magnitude of the risk of each activity and working environment conditions. Other data collected is a general description of the Nizam Zachman Fisheries Port, work procedures and other related data with this study.

Data processing and analysis techniques refer to the HIRA method listed in EMO (2012). The same method is also used by Purwangka (2013), Handayani et al. (2014), and Ismajaya et al. (2019). This research will be discussed until the risk assessment stage to determine the magnitude of the consequences of hazards that can be known in physical inspection activities and ship documents in the field with eight types of consequences, namely: fatalities, injuries, evaquation, property damage, critical infrastructure impact, environmental damage, business financial impact and social impact with the criteria listed in the following tables:

Table 1 - Scale fatalities in HIRA

\begin{tabular}{lll}
\hline Consequence & Category & Description \\
\hline 0 & None & Not likely to result in fatalities within the community \\
1 & Minor & Could result in fewer than five fatalities within the community \\
2 & Moderate & Could result in $5-10$ fatalities within the community \\
3 & Severe & Could result in $10-50$ fatalities within the community \\
4 & Catastrophic & Could result in +50 fatalities within the community \\
\hline
\end{tabular}

Source: adapted from Emergency Management Ontario 2012.

Table 2 - Scale injuries in HIRA

\begin{tabular}{lll}
\hline Consequence & Category & Description \\
\hline 0 & None & Not likely to result in injuries within the community \\
1 & Minor & Could injure in fewer than 25 people within the community \\
2 & Moderate & Could injure $25-100$ people within the community \\
3 & Severe & Could injure +100 people within the community \\
\hline
\end{tabular}

Source: adapted from Emergency Management Ontario 2012.

Table 3 - Scale evacuation in HIRA

\begin{tabular}{lll}
\hline Consequence & Category & Description \\
\hline 0 & None & Not likely to result in an evacuation shelter-in-place orders, or people stranded \\
1 & Minor & Could result in fewer than 100 people being evacuated, sheltered-in-place or stranded \\
2 & Moderate & Could result in $100-500$ people being evacuated, sheltered-in-place or stranded \\
3 & Severe & Could result in more than +500 people being evacuated, sheltered-in-place or stranded \\
\hline
\end{tabular}

Source: adapted from Emergency Management Ontario 2012. 
Table 4 - Scale property damage in HIRA

\begin{tabular}{lll}
\hline Consequence & Category & Description \\
\hline 0 & None & Not likely to result in property damage within the community \\
1 & Minor & Could cause minor and mostly cosmetic damage \\
2 & Moderate & Localized severe damage (a few buildings destroyed) \\
3 & Severe & Widespread severe damage (many buildings destroyed) \\
\hline
\end{tabular}

Source: adapted from Emergency Management Ontario 2012.

Table 5 - Scale critical infrastructure $(\mathrm{Cl})$ impact in HIRA

\begin{tabular}{lll}
\hline Consequence & Category & Description \\
\hline 0 & None & Not likely to disrupt critical infrastructure services \\
1 & Minor & Could disrupt 1 critical infrastructure service \\
2 & Moderate & Could disrupt $2-3$ critical infrastructure service \\
3 & Severe & Could disrupt more than 3 critical infrastructure service \\
\hline
\end{tabular}

Source: adapted from Emergency Management Ontario 2012.

Table 6 - Scale enviromental damage in HIRA

\begin{tabular}{lll}
\hline Consequence & Category & Description \\
\hline 0 & None & Not likely to result in environmental damage \\
1 & Minor & Could cause localized and reversible damage. Quick clean up possible \\
2 & Moderate & Could cause major but reversible damage. Full clean up difficult \\
3 & Severe & Could cause severe and irreversible environmental damage. Full clean up not possible \\
\hline
\end{tabular}

Source: adapted from Emergency Management Ontario 2012.

Table 7 - Scale business/financial impact in HIRA

\begin{tabular}{lll}
\hline Consequence & Category & Description \\
\hline 0 & None & Not likely to disrupt business/financial activites \\
1 & Moderate & Could result in losses for a few business \\
2 & Severe & Could result in losses for an industry \\
\hline
\end{tabular}

Source: adapted from Emergency Management Ontario 2012.

Table 8 - Scale psychosocial impact in HIRA

\begin{tabular}{lll}
\hline Consequence & Category & Description \\
\hline 0 & None & Not likely to result in significant psychosocial impacts \\
1 & Moderate & $\begin{array}{l}\text { Significant psychosocial impacts including limited panic, hoarding, self-evacuation and long- } \\
\text { term psychosocial impacts }\end{array}$ \\
2 & Severe & $\begin{array}{l}\text { Widespread psychosocial impacts, e.g. miss panic, widespread hoarding and self-evacuation } \\
\text { and log-term psychosocial impacts }\end{array}$ \\
\hline
\end{tabular}

Source: adapted from Emergency Management Ontario 2012.

Table 9 - Consequence worksheet

\begin{tabular}{|c|c|c|c|c|c|c|c|c|c|c|}
\hline No & $\begin{array}{l}\frac{0}{\pi} \\
\mathbb{N} \\
\text { T̃ }\end{array}$ & 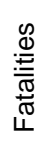 & . & 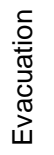 & 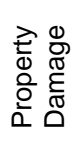 & $\begin{array}{l}\overline{0} \\
\mathbb{\mathscr { O }} \\
\stackrel{\underline{O}}{E} \\
\overline{\bar{U}}\end{array}$ & 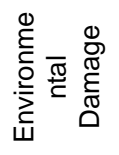 & 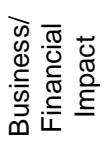 & 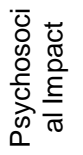 & 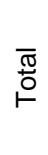 \\
\hline 1 & & & & & & & & & & \\
\hline 2 & & & & & & & & & & \\
\hline$\ldots$ & & & & & & & & & & \\
\hline
\end{tabular}

Source: adapted from Emergency Management Ontario 2012.

Table 10 - Total Consequence

\begin{tabular}{lll}
\hline Sub variable Total & Consequences & Description \\
\hline $1-4$ & 1 & Minor \\
$5-6$ & 2 & Slight \\
$7-8$ & 3 & Moderate \\
$9-10$ & 4 & Severe \\
$11-12$ & 5 & Very Severe \\
+13 & 6 & Catastrophic \\
\hline
\end{tabular}

Source: adapted from Emergency Management Ontario 2012. 


\section{RESULTS AND DISCUSSION}

Harbormaster Fishery Port Nizam Zachman is one of the Branch services that is at the forefront of the Fishery Port. Jakarta Nizam Zachman Fishery Port itself is the largest fishing port in Indonesia, located in the State Capital of Indonesia, precisely in the bay of Jakarta. The activities at the Nizam Zachman Fishery Port are not only in order to meet local demand, but also to meet national and international demand (Najah et al., 2015; MMAF, 2016).

Services carried out by the harbormaster services at the Nizam Zachman Fisheries Port Branch include Issuance of Ship Arrival Reports, Port Clearance and Issuance of Fish Catch Certification.

There are 4 harbormaster fishery field officers at the Nizam Zachman Fisheries Port. Services at the Nizam Zachman Fisheries Port Integrated Services Post are carried out daily from 8:00 am - 5:00 pm (Indonesia's time) with the final application deadline at 3:00 pm (Indonesia's time).

Based on the Regulation of the Ministry of Marine Affairs and Fisheries Republic of Indonesia Number 03 of 2013 Regarding Harbormaster at the Fishery Port that the harbormaster at the fishing port has at least 13 duties and authorities. Five of the 13 harbormaster activities are carried out directly in the field to check the data and physical compatibility of the ship before carrying out further services. Based on 5 harbormaster activities carried out in the field, they can be reduced to 3 activities namely Preharbormaster, fishing boat departure activities and post-harbormaster.

These activities are carried out with the main objective to ensure the implementation of the main tasks of the harbormaster at the Port.

Hazard potential is a condition in a process, tool, machine, material or work method that intristically/naturally can cause injury and even death in humans and cause damage to the tool and the environment. Hazard is a hazard condition that is exposed to the surrounding environment and there is a big chance of an accident/incident (Susihono and Rini 2013). Potential danger or can also be called hazard is found in almost every location where there is an activity, both at home, in the office, on the road, to the workplace (Retnowati, 2017). Occupational injury is a major problem throughout the world which especially affects developing countries (Concha-Barrientos et al. 2004).

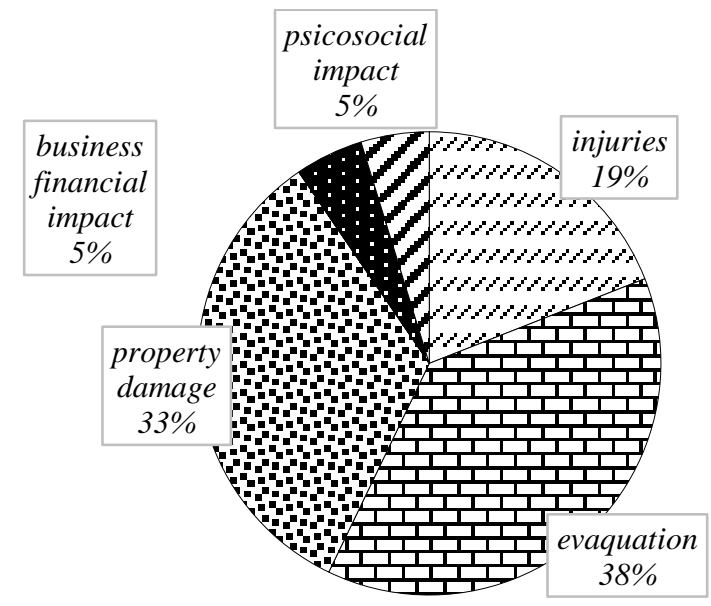

Figure 1 - The consequences of hazards in pre-harbormaster activities

In this activity fisheries harbormaster activities are more towards preparation of matters related to harbormaster officers. The observations identified five sub-activities carried out by harbormaster fishery field officers, namely: (1) Presence of attendance, (2) Breakfast, (3) Trip from the Nizam Zachman Fisheries Port office to integrated service post, (4) Trip from service post to fishing vessels, (5) Preparation of harbormaster property 
(Ship Inspection Results, measuring instruments, documentation tools). The sub-activity that gives the most value for the consequences of pre-harbormaster activities is the trip from the integrated service post to the fishing vessel with the potential danger posed namely falling into the sea. The total consequence value of these eight consequences is 30 . Shows the consequence criterion 6 (Catastrophic). Activities in the pre-harbormaster activities contribute the greatest value to Psychosocial consequences by 10 , while evaquation, property damage has a value of 0 . Figure 1 shows the percentage value of the hazard consequences of the harbormaster pre-surveillance activity.

In this activity there are 6 sub-activities, namely: (1) Inspection of ship crew documents (master, number of officers, number of crew members), (2) Inspection of Navigation Equipment, radio communication equipment, (3) Inspection of safety equipment, fire extinguishers, (4) Inspection of Fishing gear Equipment, (5) Inspection of Fishing Aids and (6) Checking the suitability of the engine number. The sub-activity with the greatest potential danger occurs in the inspection of safety equipment, fire extinguishers and pollution prevention equipment with the danger of fatigue with a consequence value of 10 . The total of the eight consequences is 112, the value is included in the consequence of criterion 6 namely Catastrophic. Activities at the ship departure inspection activity that contributed the most value were Psychosocial consequences with a total of 28 , while evaquation, property damage, and critical infrastructure had a value of 0 .

The consequences of this danger occur because when a long activity in checking vessels so it is very risky to experience fatigue that is considered trivial. Even a small danger will have an impact on these activities if the incident is repeated and ignored by fisherman harbormaster officers as stated by Supriadi (2017) that the size of an accident will have a major impact on a company and on employees who work at the company itself. Figure 2 shows the percentage value of the hazard consequences of the fishing vessel departure inspection activities by harbormaster.

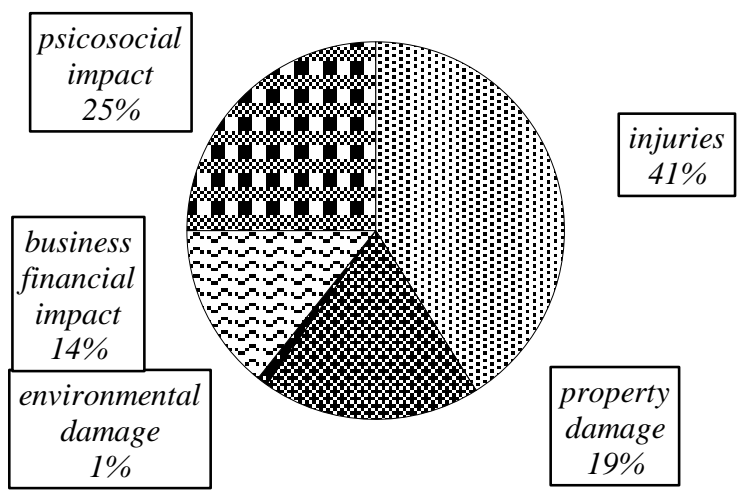

Figure 2 - The consequences of the danger in the inspection of fishing boat departure activites

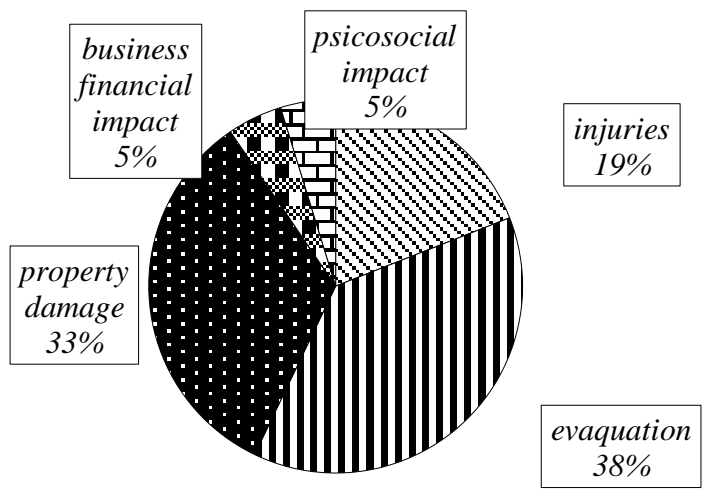

Figure 3 - The consequences of hazards in post-harbormaster activites 
Post-harbormaster activities have 3 sub-activities, namely: (1) Preparation of harbormaster property, (2) Travel from ships to the harbormaster service post, (3) Presence of return attendance. On the sub-activity the journey from the ship to the harbormaster service post provides the greatest value of the consequences with a total value of 10 consequences of the eight consequences of the activity, with the consequences of the dangers of rain and heat. A total value of 10 indicates the consequence criterion 4 , which is severe. Overall this activity provides the greatest total consequence impact on evaquation with a total consequence of 8 , while fatalities, critical infrastructure and environmental damage have no consequence value. Figure 3 shows the percentage value of the consequences of hazards from post-harbormaster surveillance activities.

\section{CONCLUSION}

The activities carried out by harbormaster field fisheries officers at the Nizam Zachman Fisheries Port have 3 main activities with the greatest value of hazard consequences on fishing boat departure activities at level 6 or Catastrophic. The suggestion from the research is that the activities carried out by harbormaster field officers in the fishing port must be supported with awareness of self and environmental safety supported by safety equipment to reduce the potential danger even though the activities carried out are routine activities every day.

\section{REFERENCES}

1. Concha-Barrientos $M$, Nelson $D$, Driscoll $T$, Steenland NK, Punnett L, Fingerhut $M$, Corvala'n C, 2004. Selected Occupational risk Factors. Comparative Quantification of Health Risks: Global And Regional Burden of Diseases Attributable to Selected Major Risk Factor. Ins. World Health Organization, Geneva, pp: 1651-1801.

2. Emergency Management Ontario [EMO]. 2012. Hazard Identification and Risk Assessment Workbook. Ontario (CA).

3. Handayani S N. 2014. Fishermen Work Safety System for Soma Pajeko (Mini Purse Seine) Fisheries in Bitung. [THESIS]. Bogor. Bogor Agricultural University.

4. Ismajaya, Purwangka F., Iskandar B. H. 2019. Level of Consequences of Danger on the Arrival and Departure of Fishing Vessel Shipment Activities at the Jakarta Service Post. Albacore:3(1).

5. Law Number 31 of 2004 concerning Fisheries.

6. Law Number 45 of 2009 concerning Amendments to Law Number 31 of 2004 concerning Fisheries.

7. Ministry of Marine Affairs and Fisheries Regulation No. 03 of 2013 concerning Harbormaster.

8. Najah R. A., Lubis E., Solihin I., Pane A. B. 2015. The Study of Catch Production Market Value in Fishing Port Nizam Zachman and Fishing Port Muara Angke. Marine Fisheries: Journal of Marine Fisheries Technology and Management, 6(2):155-167.

9. Purwangka F., Wisudo S. H., Iskandar B. H., Haluan J. 2019. Fishermen Work Safety Management Model in Palabuhanratu, Sukabumi Regency. Journal of Science and Technology Utilization of Fisheries Resources, 5 (9).

10. Retnowati D. 2017. Occupational Health and Safety Risk Analysis with the Hazard and Operability Study (Hazop) Approach. Engineering and Sains Journal 1 (1): 41-46.

11. Supriadi, Ramdan F. 2017. Hazard Identification and Risk Assessment in the Boiler Division Using the Hazard Identification Risk Assessment and Risk Control (HIRARC) Method. Journal of Industrial Hygiene and Occupational Health.1(2): 161-175.

12. Susihono W, Rini F, A. 2013. Implementation of Occupational Health and Safety (OHS) Management System and Identification of Potential Occupational Hazards (Case study in LTX, Ltd Cilegon City, Banten). Journal Spektrum Indonesia 2(2):117-242. 